\title{
Chemical characterization and antimicrobial activity of Moroccan Pelargonium asperum essential oil
}

\author{
Marwa CHRAIBI $^{1}$, Abdellah FARAH ${ }^{2}$, Mounyr BALOUIRI ${ }^{1}$, Hassan BARKAI ${ }^{1}$, Moulay SADIKI ${ }^{1}$, \\ Kawtar FIKRI BENBRAHIM ${ }^{1 *}$ \\ ${ }^{1}$ Laboratory of Microbial Biotechnology, Faculty of Science and Technology Saïss.Sidi Mohamed Ben Abdellah University, P.O.Box 2202. Fez, Morocco. \\ ${ }^{2}$ Laboratory ofApplied Organic Chemistry, Faculty of Science and Technology Saïss.SidiMohamed Ben Abdellah University, P.O.Box 2202. Fez, Morocco.
}

\begin{tabular}{|c|c|}
\hline ARTICLE INFO & ABSTRACT \\
\hline Article history: & \multirow{6}{*}{$\begin{array}{l}\text { In the aim of valorizing aromatic and medicinal plants from Morocco, this work focuses on the chemical } \\
\text { characterization and antimicrobial activity of Pelargonium asperum essential oil against } 11 \text { microbial strains } \\
\text { causing problems in the medical and food domain. The chemical profile of the volatile oil was investigated by } \\
\text { GC/MS. The major compounds were citronellol }(26.98 \%) \text {, geraniol }(14.12 \%) \text {, isomenthone }(8.80 \%) \text {, linalool } \\
(4.97 \%) \text {, citronellylformate }(3.1 \%) \text {, followed by geranylformate }(4.07 \%) \text { and guai- } 6,9 \text {-diene }(4.24 \%) \text {. The } \\
\text { results of antimicrobial activity by using the broth microdilution method indicated that essential oil of } \\
\text { Pelargonium asperum exhibited significant antimicrobial activity against all tested microorganisms with the } \\
\text { strongest inhibitory effect against yeasts. The MICs values ranged from } 0.003 \% \text { to } 0.25 \% \text { (v/v) for all strains, } \\
\text { except Pseudomonas aeruginosa, which was least susceptible and inhibited by } 2 \% \text { (v/v). These results suggest } \\
\text { that Pelargonium asperum oil could be used for the development of new antimicrobial agents. }\end{array}$} \\
\hline Received on: $03 / 10 / 2016$ & \\
\hline Revised on: $17 / 10 / 2016$ & \\
\hline Accepted on: 05/11/2016 & \\
\hline Available online: $28 / 12 / 2016$ & \\
\hline $\begin{array}{l}\text { Key words: } \\
\text { Pelargonium asperum; } \\
\text { essential oil; antimicrobial } \\
\text { activity; bacteria; fungi. }\end{array}$ & \\
\hline
\end{tabular}

\section{INTRODUCTION}

The microbiological quality of food is one of the essential foundations or basis of its ability to satisfy consumer safety. Foods exposed to deterioration by bacteria and fungi could reduce their sensory, nutritional and health characteristics (Guiraud, 2003). Despite improved food preservation techniques, natural food preservatives remain one of the most important issues for public health (Burt, 2004). In fact, several synthetic food preservatives have been limited in many countries, because of their long term side effects, including carcinogenicity (Chahardehi et al., 2010). Furthermore, antimicrobial resistance is now a global concern, which reached a crisis point in many hospitals worldwide. Indeed, there is an urgent need to replace our arsenal of anti-infective agents (Cushnie and Lamb, 2011),

\footnotetext{
* Corresponding Author

Kawtar FIKRI BENBRAHIM, Laboratory of Microbial Biotechnology,

Faculty of Science and Technology Sä̈ss. Sidi Mohamed Ben Abdellah

University, Fez, Morocco. Email: kawtar.fikribenbrahim @ usmba.ac.ma
}

by developing new antimicrobial agents. In this context, a great interest has been focused on the natural products, in particular essential oils (Bakkali et al., 2008). Essential oils are volatile components containing complex mixtures of oxygenate hydrocarbon substances having for general formula $\left(\mathrm{C}_{5} \mathrm{H}_{8}\right) \mathrm{n}$ : monoterpenes and sesquiterpenes (Deans and Svoboda, 1990). One of their apparent properties is their antiseptic power, linked to their activity against pathogenic bacteria, including some antibioticresistant strains. Several previous data already described many recipes of herbal and aromatic oils that priests and doctors employed. Currently, the use of essential oils is carried out on the scientific and rational basis, in order to develop new products for various fields: food, medical, veterinary and cosmetic. Furthermore, in the literature, several research studies have proved the antimicrobial, antiviral and insecticide properties of terpenes (Nsambu et al., 2014; Sadiki et al., 2014; Salah-Fatnassi et al., 2010). In addition, chemical complexity of the essential oils prevents the decoding from pathogens and thus reduces the risk of developing microbial resistance. 
Indeed the use of antimicrobial properties of essential oils does not start today (Beylier-Maurel, 1976), while nowadays the need to their applications became urgent. Therefore, the present study aims to determine the chemical composition of Pelargonium asperum essential oil and to investigate its antimicrobial activity by micro-dilution methods against 11 selected spoiling and pathogenic microorganisms, in an attempt to contribute to the use of these as alternative products for microbial control and food preservation.

\section{MATERIAL AND METHODS}

\section{Plant material}

Fresh aerial part of Pelargonium asperum was harvested from the garden of National Institute of the Medicinal and Aromatic Plants (NIMAP). The botanical identification was performed, and then the voucher specimen was deposited at the Herbarium of NIMAP (Morocco).

\section{Essential oil extraction}

The fresh aerial part of $P$. asperum (leaves and stems) was hydrodistilled for $3 \mathrm{~h}$ using a Clevenger-type apparatus. The essential oil was then kept in dark at $4^{\circ} \mathrm{C}$ until further use.

\section{Target strains}

Tested bacteria include seven isolates of Escherichia coli ATCC 25922, Pseudomonas aeruginosa ATCC27853, Micrococcus luteus ATCC 14452, Staphylococcus aureus ATCC 29213, Bacillus subtilis ATCC 6633, Salmonella enterica (serovar typhimurium) and Bacillus cereus. Before use, strains were revivified by subcultures in Luria-Bertani (LB) plates at $37^{\circ} \mathrm{C}$ for $24 \mathrm{~h}$. As regards the tested fungi, they include Candida albicans, Candida tropicalis, Aspergillus niger and Penicillium expansum. Revivification of molds was made by subcultures in malt extractagar plates (malt extract $30 \mathrm{~g} / \mathrm{L}$ and agar $20 \mathrm{~g} / \mathrm{L}$ ) at $25^{\circ} \mathrm{C}$ for 7 days. After incubation, their spores were harvested by scraping the culture surface in sterile Tween 20 (1\%) solution. Then the spore suspension was concentrated by centrifugation at $10000 \mathrm{~g}$ for 15 min at $4^{\circ} \mathrm{C}$ until a concentration of $10^{6}$ spores $/ \mathrm{mL}$ (counted with an hemocytometer). While, yeast strains were inoculated in yeastpeptone-glucose agar (YPG) (yeast extract $10 \mathrm{~g} / \mathrm{L}$, peptone $20 \mathrm{~g} / \mathrm{L}$, glucose $20 \mathrm{~g} / \mathrm{L}$ and agar $20 \mathrm{~g} / \mathrm{L}$ ) and incubated at $30^{\circ} \mathrm{C}$ for $48 \mathrm{~h}$.

\section{Determination of minimum inhibitory concentration against bacteria}

The minimum inhibitory concentration was determined in 96 well-microplate using the microdilution assay according to the protocol previously described by (Balouiri et al., 2016) with slight modifications. Bacteriological agar at $0.15 \%(\mathrm{w} / \mathrm{v})$ was used as an emulsifier of the essential oil in the culture medium. For bacteria, the essential oil was serially diluted in Muller Hinton broth supplemented with agar to obtain the final concentrations ranging between $8 \%$ and $0.007 \%(\mathrm{v} / \mathrm{v})$. The $12^{\text {th }}$ well was considered as growth control (free-essential oil control). Then, 50 $\mu \mathrm{L}$ of bacterial inoculum, previously prepared and adjusted to 0.5 McFarland, were added to each well to reach the final concentration of $10^{6} \mathrm{CFU} / \mathrm{mL}$. After incubation at $37^{\circ} \mathrm{C}$ for $24 \mathrm{~h}$, $10 \mu \mathrm{L}$ of resazurin were added to each well as a bacterial growth indicator.

After further incubation at $37^{\circ} \mathrm{C}$ for $2 \mathrm{~h}$, the bacterial growth was revealed by the change of coloration from purple to pink. Experiments were carried out in triplicate.

\section{Determination of Minimum inhibitory concentration against fungal strains}

To investigate the antifungal activity of the studied essential oil against Aspergillus niger and Penicillium expansum a modified microdilution technique described by (Daouk et al., 1995) was used. Firstly, $50 \mu \mathrm{l}$ of malt extract broth were added from the second to the $12^{\text {th }}$ well. The essential oil was diluted in Tween $201 \%(\mathrm{v} / \mathrm{v})$ at a final concentration of $40 \%(\mathrm{v} / \mathrm{v})$, then 100 $\mu \mathrm{L}$ of this solution were deposed in the first well. Afterwards, scalar dilution was made by transferring $50 \mu \mathrm{L}$ from the $1^{\text {st }}$ to the $11^{\text {th }}$ well. The $12^{\text {th }}$ well was considered as growth control. Thereafter $50 \mu \mathrm{L}$ of the fungal spore suspension was added to each well to reach a final concentration of $10^{6}$ spores $/ \mathrm{mL}$. The microplate was sealed and incubated for $72 \mathrm{~h}$ at $30^{\circ} \mathrm{C}$. The lowest essential oil concentration that prevents visible fungal growth was defined as the MIC. Likewise, the MIC determination against Candida albicans and Candida tropicalis, was performed in 96 well-microplate according to the protocol previously described (Balouiri et al., 2016) with slight modifications. The essential oil was also serially diluted in YPG broth supplemented with agar at $0.15 \%(\mathrm{w} / \mathrm{v})$. The $12^{\text {th }}$ well was also considered as growth control. Then, $50 \mu \mathrm{L}$ of fungal inoculum were added to each well at a final concentration of $10^{3} \mathrm{CFU} / \mathrm{mL}$. Finally, the microplate was sealed and incubated at $30^{\circ} \mathrm{C}$ for $48 \mathrm{~h}$. Experiments were carried out in triplicate. Similarly, the lowest essential oil concentration that prevents visible fungal growth was defined as the MIC.

\section{RESULTS AND DISCUSSION}

The studied essential oil was previously subjected to a gas chromatography-mass spectrometry analysis. This analysis revealed 61 different compounds accounting for $99.96 \%$ of the whole Pelargonium asperum essential oil, where the major constituents were citronellol (26.98\%), geraniol (14.12\%), isomenthone $(8.80 \%)$, linalool $(4.97 \%)$, geranylformiate $(4.07 \%)$, guaï-6,9-diene (4.24\%) and citronellyl formiate (3.1\%). Likewise, several previous studies have found citronellol as the principal major component of this essential oil (Boukhatem et al., 2013; Boukhris et al., 2013; Bouzenna and Krichen, 2013; Gomes et al., 2007; Jalali-Heravi et al., 2006).

\section{Antibacterial effect of Pelargonium asperum essential oil}

This study focused on the Pelargonium asperum essential oil bioactivity. Results found of its antimicrobial activity 
evaluated against 11 microbial strains are compiled in Tables (Tab. 1, 2 and 3).

As regards to the antibacterial effect, it can be seen in the Tab. 1 that all tested bacterial strains were susceptible to the studied essential oil. The antibacterial effect unveiled seems to be strain- dependent. In fact, strong inhibitory effect has been shown against all Gram-positive bacteria, especially Bacillus cereus and Micrococcus luteus, since they were inhibited by very low concentrations $0.007 \%$ and $0.015 \%$ (v/v) respectively. In addition, the concentration of $0.031 \%(\mathrm{v} / \mathrm{v})$ was sufficient to inhibit the growth of $S$. aureus and B. subtilis. Against Gram-negative bacteria the tested essential oil was more active against $E$. coli and $S$. enterica serovar typhimurium with a minimum inhibitory concentration of $0.125 \%(\mathrm{v} / \mathrm{v})$. In contrast, $P$. aeruginosa was the most resistant strain with MIC value of $2 \%(\mathrm{v} / \mathrm{v})$. Previous studies confirmed that this bacterial strain was the most resistant (Boukhatem et al., 2013; Ghannadi et al., 2012; Haloui et al., 2015). Usually, the Gram-positive strains were more susceptible to the essential oils than the Gram-negative bacteria. This difference is closely related to their cell wall compositions, since the antibacterial activity of the essential oils has been explained by molecular interactions of the functional groups of their components and the bacterial wall, which inflict several damages to the cell (Calo et al., 2015).

In fact, the outer membrane of Gram-negative bacteria is characterized by the presence of lipopolysaccharides (75\%), which have hydrophilic character that makes the outer membrane of these bacteria invulnerable to the most hydrophobic molecules (i.e. Hydrocarbons terpenes). Thus, this structural particularity is in part responsible for the intrinsic resistance of Gram-negative compared to the Gram-positive bacteria to the essential oils constituents (Gachkar et al., 2007; Trombetta et al., 2005). Furthermore, concerning the antifungal activity against molds and yeasts (Tab. 3 and 4), the screening test revealed that all tested fungal strains were susceptible to the Pelargonium asperum oil. Indeed, the strongest inhibitory effect was exerted against yeasts (both Candida species) with MIC values of $0.003 \%$ and $0.007 \%$ (v/v) against Candida albicans and Candida tropicalis respectively. These results are in agreement with those of previous works (Boukhatem et al., 2013; Hassane et al., 2011). As regards to the molds they were inhibited with MIC values of $0.312 \%$ and $0.15 \%$ (v/v) against Penicillium expansum and Aspergillus niger respectively. The broad spectrum and the significant antimicrobial activity of the tested essential oil may be attributed to its richness in terpenic alcohols (citronellol, geraniol, linalool), which represent $46.07 \%$ of its total composition. In fact, these molecules are well-known for their greater efficiency as antimicrobials (Hammer et al., 2003; Inouye et al., 2001; Satrani et al., 2006). In addition, among the identified compounds in this oil, some molecules were previously reported to exhibit antimicrobial activity such as limonene (Mazzanti et al., 1998), geraniol (Araújo et al., 2003), carvacrol and citronellol (Sacchetti et al., 2005).

In addition, this antimicrobial outcome could also be attributed to the synergistic interaction between the various components of this oil. In fact, it has been reported in previous studies that the inhibitory activity of an essential oil results from a complex interaction between its different constituents (Burt, 2004; Viuda-Martos et al., 2008; Xianfei et al., 2007).

Table 1: Chemical composition of Geranium (Pelargonium asperum) essential oil.

\begin{tabular}{|c|c|c|}
\hline KI & Constituants & Percentages \\
\hline 931 & $\alpha$-Thujene & 0.50 \\
\hline 1074 & Cis-oxidelinalol & 0.54 \\
\hline 1097 & Linalol & 4.97 \\
\hline 1111 & Cis-oxide rose & 0.82 \\
\hline 1134 & Terpinol-1 & 0.95 \\
\hline 1143 & Cis-Sabinol & 0.59 \\
\hline 1164 & Isomenthone & 8.80 \\
\hline 1189 & $\alpha$-Terpineol & 0.70 \\
\hline 1228 & Citronellol & 26.98 \\
\hline 1240 & Carvone & 0.53 \\
\hline 1255 & Geraniol & 14.12 \\
\hline 1270 & Geraniale & 0.73 \\
\hline 1275 & Citronellyl formiate & 7.09 \\
\hline 1300 & Geranyl Formiate & 4.07 \\
\hline 1349 & $\alpha$-Terpinylacetate & 0.54 \\
\hline 1353 & Citronellylacetate & 1.24 \\
\hline 1384 & $\beta$-Bourbonene & 0.57 \\
\hline 1419 & $\beta$-Caryophyllene & 0.76 \\
\hline 1443 & Guaï-6,9-diene & 4.27 \\
\hline 1474 & $\beta$-Thujaplicin & 1.09 \\
\hline 1484 & $\gamma$-Thujaplicin & 0.71 \\
\hline 1526 & $\Delta$-Cadinene & 0.51 \\
\hline 1538 & $\alpha$-Cadinene & 0.56 \\
\hline 1558 & 1-nor-epi-Bouronanone & 1.09 \\
\hline 1585 & NerylIsovalerate & 0.96 \\
\hline 1586 & Davanone & 1.95 \\
\hline \multirow[t]{2}{*}{1697} & (E)-Citronellyltiglate & 1.42 \\
\hline & Total & 99.96 \\
\hline
\end{tabular}

KI: Kovàt's indices, MS: NIST 98 spectra and the literature (Adams 1995), ST: Co injection with authentic standards\% (v/v) 
Table 2: Antibacterial activity of Pelargonium asperum essential oil

\begin{tabular}{|c|c|c|c|c|c|c|c|c|c|c|c|c|}
\hline \multirow[b]{2}{*}{ Strains } & \multicolumn{12}{|c|}{ Concentrations v/v } \\
\hline & $\begin{array}{l}8 \% \\
(v / v)\end{array}$ & $\begin{array}{c}4 \% \\
(v / v)\end{array}$ & $\begin{array}{c}2 \% \\
(v / v)\end{array}$ & $\begin{array}{l}1 \% \\
(\mathrm{v} / \mathrm{v})\end{array}$ & $\begin{array}{l}0.5 \% \\
(v / v)\end{array}$ & $\begin{array}{c}0.25 \% \\
(\mathrm{v} / \mathrm{v})\end{array}$ & $\begin{array}{c}0.125 \% \\
(v / v)\end{array}$ & $\begin{array}{c}0.062 \% \\
(v / v)\end{array}$ & $\begin{array}{c}0.031 \% \\
(v / v)\end{array}$ & $\begin{array}{c}0.015 \% \\
(v / v)\end{array}$ & $\begin{array}{c}0.007 \% \\
(v / v)\end{array}$ & control \\
\hline S. aureus & - & - & - & - & - & - & - & - & - & + & + & + \\
\hline Bacillus subtilis & - & - & - & - & - & - & - & - & - & + & + & + \\
\hline Bacillus cereus & - & - & - & - & - & - & - & - & - & - & - & + \\
\hline M. luteus & - & - & - & - & - & - & - & - & - & - & + & + \\
\hline Escherichia coli & - & - & - & - & - & - & + & + & + & + & + & + \\
\hline P. aeruginosa & - & - & - & + & + & + & + & + & + & + & + & + \\
\hline Salmonella typhi & - & - & - & - & - & - & - & + & + & + & + & + \\
\hline
\end{tabular}

S. aureus : Staphylococcus aureus ; M. luteus : Micrococcus luteus ; P. aeruginosa : Pseudomonas aeruginosa.

Table 3: Antifungal activity of Pelargonium asperum essential oil against Candida albicans and Candida tropicalis.

\begin{tabular}{|c|c|c|c|c|c|c|c|c|c|c|c|c|}
\hline \multirow[b]{2}{*}{ Strains } & \multicolumn{12}{|c|}{ Concentrations \% (v/v) } \\
\hline & $\begin{array}{l}4 \% \\
(\mathrm{v} / \mathrm{v})\end{array}$ & $\begin{array}{l}2 \% \\
(v / v)\end{array}$ & $\begin{array}{l}1 \% \\
(\mathrm{v} / \mathrm{v})\end{array}$ & $\begin{array}{l}0.5 \% \\
(\mathrm{v} / \mathrm{v})\end{array}$ & $\begin{array}{c}0.25 \% \\
(\mathrm{v} / \mathrm{v})\end{array}$ & $\begin{array}{c}0.125 \% \\
(v / v)\end{array}$ & $\begin{array}{c}0.062 \% \\
(\mathrm{v} / \mathrm{v})\end{array}$ & $\begin{array}{c}0.031 \% \\
(v / v)\end{array}$ & $\begin{array}{c}0.015 \% \\
(v / v)\end{array}$ & $\begin{array}{c}0.007 \% \\
(v / v)\end{array}$ & $\begin{array}{c}0.003 \% \\
(v / v)\end{array}$ & Control \\
\hline C. albicans & - & - & - & - & - & - & - & - & - & - & - & + \\
\hline C. tropicalis & - & - & - & - & - & - & - & - & - & - & + & + \\
\hline
\end{tabular}

C. albicans: Candida albicans and C. tropicalis: Candida tropicalis.

Table 4: Antifungal activity of Pelargonium asperum essential oil against Aspergillus niger and Penicillium expansum.

\begin{tabular}{|c|c|c|c|c|c|c|c|c|c|c|c|c|}
\hline \multirow[b]{2}{*}{ Strains } & \multicolumn{12}{|c|}{ Concentrations v/v } \\
\hline & $\begin{array}{l}20 \% \\
(v / v)\end{array}$ & $\begin{array}{l}10 \% \\
(v / v)\end{array}$ & $\begin{array}{c}5 \% \\
(v / v)\end{array}$ & $\begin{array}{l}2.5 \% \\
(\mathrm{v} / \mathrm{v})\end{array}$ & $\begin{array}{l}1.2 \% \\
(v / v)\end{array}$ & $\begin{array}{c}0.625 \% \\
(v / v)\end{array}$ & $\begin{array}{c}0.312 \% \\
(v / v)\end{array}$ & $\begin{array}{c}0.15 \% \\
(v / v)\end{array}$ & $\begin{array}{c}0.075 \% \\
(v / v)\end{array}$ & $\begin{array}{c}0.037 \% \\
\text { (v/v) }\end{array}$ & $\begin{array}{c}0.018 \% \\
(v / v)\end{array}$ & control \\
\hline A. niger & - & - & - & - & - & - & - & - & + & + & + & + \\
\hline P. expansum & - & - & - & - & - & - & - & + & + & + & + & + \\
\hline
\end{tabular}

A. niger : aspergillus niger ; P. expansum : Penicillium expansum.

\section{CONCLUSION}

The findings highlighted that $P$. asperum essential oil was able to inhibit the growth of a wide spectrum of microbial strains, known for their implications in human and animal infections. Its content on several active compounds and their interactions explained well its bioactivity. Hence, this essential oil can be a promising agent to control microbial growth, even if more detailed reports on its toxicity and mechanisms of action are requested to overcome the impediment of its application in several industries.

\section{ACKNOWLEDGMENTS}

Author's like to thank the Director and all the staff of the National Institute of the Medicinal and Aromatic Plants (NIMAP) - Taounate, Morocco.

\section{Financial support and sponsorship: Nil}

Conflict of Interests: There are no conflicts of interest.

\section{REFERENCES}

Araújo C, Sousa MJ, Ferreira MF, Leão C. Activity of Essential Oils from Mediterranean Lamiaceae Species against Food Spoilage Yeasts. J Food Prot, 2003 ; 66:625-632.

Bakkali F, Averbeck S, Averbeck D, Idaomar M. Biological effects of essential oils--a review. Food Chem Toxicol, 2008; 46:446-475.

Balouiri M, Sadiki M, Ibnsouda SK. Methods for in vitro evaluating antimicrobial activity: A review. J Pharm Anal, 2016; 6:71-79.
Beylier-Maurel MF. Activité bactériostatique de certaines matières premières de parfumerie. Riv Ital EPPOS, 1976; 58:283-286.

Boukhatem MN, Kameli A, Saidi F. Essential oil of Algerian rose-scented geranium (Pelargonium graveolens): Chemical composition and antimicrobial activity against food spoilage pathogens. Food Control, 2013; 34:208-213.

Boukhris M, Ben Nasri-Ayachi, M, Mezghani I, Bouaziz M, Boukhris M, Sayadi S. Trichomes morphology, structure and essential oils of Pelargonium graveolens L'Her. (Geraniaceae). Ind Crops Prod, 2013; 50:604-610.

Bouzenna H, Krichen L. Pelargonium graveolens L'Her. and Artemisia arborescens L. essential oils: chemical composition, antifungal activity against Rhizoctonia solani and insecticidal activity against Rhysopertha dominica. Nat Prod Res, 2013; 27:841-846.

Burt S. Essential oils: Their antimicrobial properties and potential applications in foods: A review. Int J Food Microbiol, 2004; 94:223-253.

Calo JR, Crandall PG, O’Bryan CA, Ricke SC. Essential oils as antimicrobials in food systems - A review. Food Control, 2015; 54:111119.

Chahardehi AM, Ibrahim D, Sulaiman SF. Antioxidant, antimicrobial activity and toxicity test of Pilea microphylla. Int $\mathrm{J}$ Microbiol, 2010; 2010:1-7.

Cushnie TPT, Lamb, AJ. Recent advances in understanding the antibacterial properties of flavonoids. Int J Antimicrob Agents, 2011; 38: 99-107.

Daouk RK, Dagher SM, Sattout EJ. Antifungal Activity of the Essential Oil of Origanum syriacum L. J Food Prot, 1995; 58:1147-1149.

Deans S, SvobodaKP. Biotechnology and bioactivity of culinary and medicinal plants. Int Inf Syst Agric Sci Technol, 1990; 2:211216.

Gachkar L, Yadegari D, Rezaei, MB, Taghizadeh M, Astaneh SA, Rasooli I. Chemical and biological characteristics of Cuminum cyminum and Rosmarinus officinalis essential oils. Food Chem, 2007; 102:898-904. 
Ghannadi A, Bagherinejad MR, Abedi D, Jalali M, Absalan B, Sadeghi N. Antibacterial activity and composition of essential oils from Pelargonium graveolens L'Her and Vitex agnus-castus L. Iran J Microbiol, 2012; 4:171-176.

Gomes PB, Mata VG, Rodrigues AE. Production of rose geranium oil using supercritical fluid extraction. J Supercrit Fluids, 2007; 41:50-60.

Guiraud JP. 2003. Microbiologie alimentaire. Paris, France: Dunod: RIA, DL.

Haloui T, Farah A, Balouiri M, Chraibi M, Fadil M, Benbrahim K, Alaoui A. Bacteriostatic and Bactericidal Profile of Leaves and Twigs Essential oils of Moroccan Pistacia lentiscus L. J Appl Pharm Sci, 2015; 5:50-53.

Hammer KA, Carson CF, Riley T V. Antifungal activity of the components of Melaleuca alternifolia (tea tree) oil. J Appl Microbiol, 2003; 95:853-860.

Hassane SOS, Ghanmi M, Satrani B, Mansouri N, Mohamed H, El Hajaji H, Chaouch A. Composition chimique et activités antibactériennes, antifongiques et antioxydante de l'huile essentielle de Pelargonium asperum Ehrh. ex Wilde des Comores. Acta Bot Gall, 2011; 158:225-237.

Inouye S, Takizawa $\mathrm{T}$, Yamaguchi $\mathrm{H}$. JAC Antibacterial activity of essential oils and their major constituents. J Antimicrob Chemother, 2001; 47:565-573.

Jalali-Heravi M, Zekavat B, Sereshti H. Characterization of essential oil components of Iranian geranium oil using gas chromatography-mass spectrometry combined with chemometric resolution techniques. J Chromatogr A, 2006 ;1114:154-163.

Mazzanti G, Battinelli L, Salvatore G. Antimicrobial properties of the linalol-rich essential oil of Hyssopus officinalis L . var decumbens ( Lamiaceae ). Flavour Frag J, 1998; 13:289-294.

Nsambu M, Muhigwa B, Rubabura K, Bagalwa M, Bashwira S. In vitro evaluation of the insecticidal activity of alkaloids, saponins, terpenoids and steroids extracts Capscicum frutescens L. (Solanaceae) against Antestiopsis orbitalis ghesquierei, pest insects of cafeirs. Int J Innov Appl Stud, 2014; 8:1231-1243.

Sacchetti G, Maietti S, Muzzoli M, Scaglianti M, Manfredini S, Radice M, Bruni R, Comparative evaluation of 11 essential oils of different origin as functional antioxidants, antiradicals and antimicrobials in foods. Food Chem, 2005; 91:621-632.
Sadiki M, Balouiri M, Barkai H, Maataoui H, Ibnsoud S, Elabed S. Synergistic antibacterial effect of Myrtus communis and Thymus vulgaris essential oils fractional inhibitory concentration index. Int $\mathrm{J}$ Pharm Pharm Sci, 2014; 6:121-124.

Salah-Fatnassi KBH, Slim-Bannour A, Harzallah-Skhiri F, Mahjoub MA, Mighri Z, Chaumont JP, Aouni M. Activités antivirale et antioxydante in vitro d'huiles essentielles de Thymus capitatus (L.) Hoffmans. \& Link de Tunisie. Acta Bot Gall, 2010; 157:433-444.

Satrani B, Farah A, Talbi M. Effet de la distillation fractionnée sur la composition chimique et l'activité antimicrobienne des huiles essentielles du Myrte (Myrtus communis L.) du Maroc. Acta Bot Gall, 2006; 153:235-242.

Trombetta D, Castelli F, Sarpietro MG, Venuti V, Cristani M, Daniele C, Saija A, Mazzanti G, Bisignano G, Grazia M. Mechanisms of Antibacterial Action of Three Monoterpenes Mechanisms of Antibacterial Action of Three Monoterpenes. J Antimicrob Agents Chemother, 2005; 49:2474-2478.

Viuda-Martos M, Ruiz-Navajas Y, Fernández-López J, PérezÁlvarez JA. Antibacterial activity of different essential oils obtained from spices widely used in Mediterranean diet. Int J Food Sci Technol, 2008; 43:526-531.

Xianfei X, Xiaoqiang C, Shunying Z, Guolin Z. Chemical composition and antimicrobial activity of essential oils of Chaenomeles speciosa from China. Food Chem, 2007; 100:1312-1315.

\section{How to cite this article:}

Chraibi M, Farah A, Balouiri M, Barkai H, Sadiki M, Benbrahim KF. Chemical characterization and antimicrobial activity of Moroccan Pelargonium asperum essential oil. J App Pharm Sci, 2016; 6 (12): 042-046. 